\title{
THE USE OF STILBOESTROL IN THE TREATMENT OF CARCINOMA OF THE PROSTATE
}

\section{By J. CHESNEY, M.D. \\ (Honorary Resident Assistant Surgeon to St. Paul's Hospital for Genito-urinary Diseases)}

The modern treatment of carcinoma of prostate is remarkable in having for its foundation not only a great store of knowledge won by clinical observation, but also a rich accumulation of physiological, biochemical and pathological facts established by experiment.

\section{Incidence.}

The view expressed by Sir Henry Thompson over seventy-five years ago that carcinoma of the prostate is far more prevalent than generally supposed, has been confirmed by many observers in the last four decades (Albarran and Hallé, Freyer, Wade, Jocelyn Swan, ThomsonWalker, Dossot; Swift Joly, W. K. Irwin, Colston).

H. H. Young estimates that carcinoma is present in about 20 per cent of cases arriving at his clinic with prostatic obstruction. R. A. Moore found carcinomatous changes in sections of prostates in 21 per cent of 252 patients over forty years of age. His observations are based on routine autopsy material at two hospitals in Vienna. Statistical data collected from all the London hospitals were recently brought forward by the Medical Secretary to the Clinical Cancer Research Committee of the British Empire Cancer Campaign. They show that of I5,200 cases of cancer registered from April I, I938, to September 3, I939, there were 382 cases of primary carcinoma of the prostate.

The figures for St. Paul's Hospital are not available at the present moment. My own observations in the Out-Patient Department, for the last twelve years, indicate that carcinoma of the prostate is the most frequent malignant disease of the male genito-urinary tract.

\section{Localisation and Pathology.}

Carcinoma arises quite often in an apparently normal gland, and the changes are neoplastic from the outset. Malignant changes may also occur in simple adenoma, or the two conditions co-exist in different parts of the gland. They can precede each other by many years. Carcinoma is known sometimes to develop in the prostatic bed a number of years after enucleation of a simple adenoma.

Adenocarcinoma is the commonest type seen, but there are many variations in its structure. The scirrhus is more insidious and slow-growing. Basal cell adenocarcinoma and solid carcinoma derived from hyperplasia of the undifferentiated supporting epithelium of the ducts and acini have also been described (Krompecher). The symptoms and signs of the disease, its origin and its spread are well known from detailed publications by Swift Joly, H. H. Young and Dossot.

\section{Metastases.}

Skeletal metastases occur quite frequently and affect the lumbo-sacral spine, the bones of the pelvic girdle, the long bones, ribs and skull.

Visceral metastases are not very common and are found mostly in the lungs, and less often in the liver or kidneys. The brain and skin are rarely affected. Secondaries in the spinal cord have been met with in I per cent of cases (Bumpus), and their symptoms and signs closely resemble spinal cord tumours.

The iliac, para-aortic, inguinal, cervical and supra-clavicular lymph glands are involved sooner or later. The cellular tissue of the pelvis may become infiltrated, and sometimes the whole pelvis is invaded by a large tumour. It compresses the iliac vessels, the obturator nerves and the sacral plexus. Anteriorly it spreads on each side of the bladder up to the symphysis. The condition is known as prostato-pelvic carcinosis (Guyon).

\section{BIOCHEMICAL DIAGNOSIS}

Recent investigations by many observers have stressed the importance of serum acid phosphatase estimation in the diagnosis, differential diagnosis, prognosis, and in the evaluation of effects of treatment by Androgen control. The phosphatases were first described in I9I2 by Grosser and Husler. 
Both acid and alkaline phosphatase are enzymes, and are found in tissues and fluids of the body. They are colloidal organic catalysts, and their action consists in quickening up the process of splitting off phosphate ions from certain organic compounds. They act either on the acid or alkaline side of neutrality, and hence their name. There is an optimum hydrogen ion concentration of the medium in which each enzyme is most active, about $\mathrm{pH} 5 \cdot 0$ for acid phosphatase, and about $\mathrm{pH} 9 \cdot 0$ for alkaline phosphatase. Acid phosphatase has its own pattern of distribution in the tissues, as shown by the special stain of Gomori.

The blood serum of normal individuals contains $0 \cdot 5-2 \cdot 5$ units of acid phosphatase. Values between 5 and Io units give a strong suspicion of carcinoma, and values over ro units are believed to be diagnostic. The normal levels for alkaline phosphatase are 4-I3 King and Armstrong units, or I-4 Bodansky units. The number of units is meant to express the amount of phosphatase in Ioo c.c. of serum. 5 c.c. of blood is quite sufficient for the test. Haemolysis is to be avoided, and the fresh serum must be pippeted off as soon as possible.

Dmochowski, Kutcher and Wolbergs, Sullivan, and the Gutmans have investigated the sources of acid phosphatase in the seminal fluid, urine and blood. They were able to prove that adult prostatic tissue produces acid phosphatase, which is found in the prostatic fluid and urine of normal individuals. Huggins and his co-workers have presented evidence that prostatic carcinoma and its metastases are composed of epithelial cells resembling adult prostatic epithelium in their structure and function, and they are thus capable of producing large quantities of acid phosphatase. As soon as carcinomatous cells begin to infiltrate the blood and lymph vessels, the serum acid phosphatase begins to rise. High levels are an indication that metatases are already present or likely to occur, even if the clinical and radiological findings are negative. The test also confirms the prostatic origin of secondaries, both visceral and skeletal, when the site of the primary growth remains still in doubt. In only 15 per cent of cases is carcinoma of prostate composed of cells of an embryonic type, and the level of serum acid phosphatase remains normal (Gutman). Rapid increasing levels of serum acid phosphatase is considered as an unfavourable prognostic sign.

The estimation of serum alkaline phosphatase is important in differential diagnosis between skeletal metastases of prostatic origin and Paget's disease of bone and osteoporosis. In the latter two diseases the alkaline phosphatase is far above normal and the acid phosphatase remains normal.

\section{TREATMENT}

In the treatment of patients two problems have to be solved, (I) the correction of urinary obstruction, and (II) the control of the malignant growth.

I. In complete obstruction an indwelling catheter is tied in for a few days and the bladder gradually decompressed. A permanent suprapubic cystostomy is the operation of choice. Patients live much longer and in comparative comfort after cystostomy than after a more radical operation. Per-urethral resection has also been carried out in incomplete obstruction. In a number of cases it is quite impossible to introduce the McCarthy resectoscope. The operation has to be repeated on many occasions, and it may leave a growth-promoting septic area at the bladder outlet (Morson).

Few patients are fit enough to stand a bilateral transplantation of ureters into the large bowel. The convalescence is long and stormy, and they often suffer afterwards from a bilateral B. coli pyelonephritis.

\section{The control of the malignant growth.}

From observations on the experimental animal a great deal of evidence has been accumulated regarding the functional relationship between the prostate and some of the known glands of internal secretion, i.e. the testes, pituitary, and ovaries.

Laboratory and clinical tests were carried out by Huggins and his colleagues, and by many other observers. They were able to prove that normal and carcinomatous prostatic epithelium is stimulated by androgens, and suppressed to a great extent by oestrogens.

The term androgen is generally used to define any substance which has masculinizing properties. It is mostly secreted by the interstitial cells of the testes (Testosterone), but there exist also extra-testicular sources of androgen.

Huggins observed regression of prostatic carcinoma only in 50 per cent of cases treated 
with bilateral castration. The suprarenal glands are believed to be at least one of the sources of androgen formation. The gonadotrophic hormone of the anterior pituitary controls the production of androgen by the testes.

Oestrogens are hormones of the ovary, and the principal natural oestrogen is known as oestradiol benzoate. Dodds and his co-workers produced a synthetic oestrogen compound of simpler chemical structure known as stilboestrol. It is actually more potent than oestradiol benzoate, and has the advantage of being effective both orally and by injection.

Oestrogens seem to have no direct suppressive action on the functional activity of the testes. Their prolonged administration causes functional and structural changes in the anterior pituitary. They inhibit the secretion of pituitary gonadotrophic hormone, and indirectly cause suppression of androgen production by the testes.

Bilateral castration as a method of treatment has been suggested by $\mathrm{J}$. W. White, of Philadelphia, many years ago, and has since been carried out on a number of patients. Its effect on the growth is similar to the administration of oestrogens, but the psychological trauma caused by such an operation may exceed the advantages gained by it.

\section{Dosage of Stilboestrol.}

Patients are treated by oral administration of stilboestrol in doses of $\mathrm{I}_{2} \frac{1}{2} 5 \mathrm{mgm}$., or by intramuscular injection of $5 \mathrm{mgm}$. (I c.c.) twice or three times a week. The dose must vary with each individual. An extensive growth with numerous metastases is treated with higher doses, and not less than Io mgm. daily by injection. The effects of treatment are controlled clinically, radiologically and serologically. As soon as the serum acid phosphatase is reduced to normal levels a small maintenance dose of stilboestrol is prescribed. In every case under my observation there was a softening of the stony hard prostate with diminution in its size, and a decrease in the amount of residual urine. The patients gained weight and were free from pain for longer intervals. In every case the breasts were swollen and the nipples pigmented. Disappearance of metastases was noticed by many observers. Histological examination of prostatic tissue gained by endoscopic resection showed marked regressive changes (Kahle et. al., Riches).

H. H. Young carried out total perineal prostatectomy in a selected group of 76 cases with a mortality of 8 per cent. His excellent operative results have never been surpassed.

I think that certain features of the disease and its spread with an early involvement of the capsule and of the regional lymph glands often precludes the effective application of radical surgery. The essential clinical, radiological and laboratory criteria for a successful operation were absent in all our cases.

\section{Conclusions}

From the research and clinical point of view it is now possible to confirm that carcinomatous prostatic cells respond to the same internal secretion stimuli and inhibitions as the normal prostate. The biochemical control can be confirmed by a low serum acid phosphatase level, and the test should be repeated every 2 months.

The spread of carcinoma may be definitely modified by castration, or preferably by the administration of oestrogens. No cures have been observed, and the ultimate fate of the patients remains unknown. The results of treatment are not uniformly successful.

The introduction of a new method of treatment is often associated with conflicting opinions regarding its application. Considerable time must elapse before its acceptance becomes general, and its indications fully standardised.

I wish to express my thanks to Mr. W. K. Irwin for his kind permission to carry out my observations on a number of his patients.

\section{REFERENCES}

ALBARRAN and HALLE (I9oo), Ann. des mal. org. gen. urin., 113 and 225.

BARRINGER, B. S. (1943), Bull. New York Acad. of Med., Vol. 19, 6, 4 I7.

BODANSKY, A. (1937), Jour. Biol. Chem., 120, 167.

BOWLER, J. P., and PEDLEY, S. F. (1944), New Eng. J. of Med., 230, I7, 501.

BUMPUS, H. C.'(1926), Surg. Gyn. Obst., 43, I50.

COLSTON, J. A. C. (I943), J.A.M.A., 122, 781 .

DEAN, A. L., WOODWARD, H. Q., and TWOMBLY, G. H. (1943), J. Urol., 49, r, 108. 
DMOCHOWSKI, A. (1933), Compt. Rend. Soc. de Biol., 113, 956.

DODDS, E. C. (1943), Middx. Hosp. J., 43, 3,38 .

DODDS, E. C. (I944), Proc. $R$. Soc. Med., Vol. 37, 7, 353.

DOSSOT, R. (1926), These de la Fac. de Med. de Paris. Arch. Urol. de la Clin. de Necker, T.V. Fasc., 4, 257.

FERGUSON, J. D. (1944), Lancet, May 6th.

GERAGHTY, J. T. (1922), J. Urol., 7,33 .

GOMORI, G. (194I), Arch. Path., 32, 189.

GREEN, L. F., and THOMPSON, G. F. (1944), Proc. Staff Meet. Mayo Clinic, 19, 3.

GROSSER, P., and HUSLER, J.'(1912), Biochem. Zeitschr., 39, x.

GUTMAN, A. B. (1942), J.A.M.A., 120 , 1112.

HERBST, W. P. (1942), J.A.M.A., 120, 1116.

HIGGINS, C. C., and GOSSE, C.'L. (r942), Cleveland Clin. Quart., 9, 2.

HUGGINS, C. (1942), Ann. Surg., 115, 1192 .

HUGGINS, C., and HODGES, C. V. (I94I), Cancer Res., 1, 293.

HUGGINS, C., SCOTT, w. W., and HODGES, C. V. (194I), J. Urol., 46, 997.

HUGGINS, C., and STEVENS,' R. E. (r940), J. Urol., 43, 705.

HUGGINS, C., and CLARK, P. J. (1940), J. Exp. Med., 72, 747; (1943), Science, 97, $54 \mathrm{I}$.

IRWIN, W. K. (1927), Urinary Surgery.

JOLY, J. S. (1941), Post-Grad. Med. Journ., 17, 189, 125.

KAHLE, P. J., SHENKEN, J. R., and BURNS, E. L. (I943), J. Urol., 50, 71 I.

KING, E. J., and ARMSTRONG, A. R. (r934), Canad. M.A.J., 31, 376.

KORENCHEVSKY, V., and DENNISON, M. (I935), Proc. $R$. Soc. Med., 28, 1265.

KROMPECHER, E. (1925), Virchows Arch. f. Path. A nat. 257, 284.

KUTCHER, W., and WOLBERGS, N. (I935), Ztschr. f. Physiol Chem., 236, 237.

LOWSLEY, O. S., et al. (1942), The Sex Glands of the man.

MARION, G. (1926), Jour. d'Urol., 21, 385 .

MILLS, C. H. (1944), Personal Communication.

MOORE, R. A. (1935), J. Urol., 33, 224.

MORSON, C. (I944), Proc. R. Soc. Med., Vol. 37, 7, 350

RICHES, E. W. (1944), Proc. $R$. Soc. Med., Vol. 37, 7, 357.

SATTERTHWAITE, R. W., HILL, J. H., and PACKARD, E. P. (194I), J. Urol., 46, II49.

SULLIVAN, T. J., GUTMA'N, E. B., and'GUTMAN, A. B. (1942), J. Urol., 48, 426.

SWAN, R. H. J. (1923), Proc. R. Soc. Med., Sect. Urol., 16, 3,71 .

THOMPSON, Sir HENRY (1868), Diseases of the Prostate, 3 rd Ed.

THOMSON-WALKER, Sir JOHN (1936), Surg. Dis. and Inj. G.U. Org.

WADE, H. (1914), Ann. Surg., 59, 321 .

WHITE, J. W. (1895), Ann. Surg., 22, I.

WINSBURY Y-WHITE, H. P. (1936), Med. World.

WRIGHT, S. (1942), Applied Physiology.

YOUNG, 'H. H. (1936), Surg. Clin., N. Amer., 16, 1273.

YOUNG, H. H. (1937), Surg. Gyn. and Obst., 64, 472 .

YOUNG, H. H. (1940), see Pack, G. T., and Livingston, E. M., Treatment of Cancer and Allied Diseases, Vol. 3, 1960.

\section{INEECTION}

\section{The high prophylactic value of $\operatorname{BEMMA}$ *}

A sufficiency of at least five factors of the B complex has been shown experimentally to be essential for maintaining normal phagocytic functions. ${ }^{1}$ So also has a satisfactory protein intake.

Bemax, with a digestible protein content of over 30 per cent. and containing so many factors of the $B$ complex including vitamins $B_{1}$ and $B_{6}$, should therefore be of signal service in building a high resistance to infection. It should be used especially in the last 3 months of pregnancy.

I F. Immunol 1943, $47: 493$

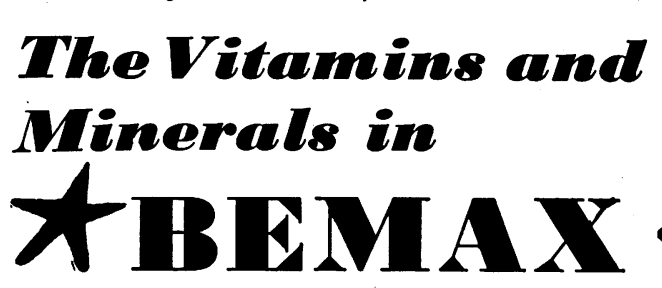

Vitamins Limited, 23, Up per Mall, London, W.6.

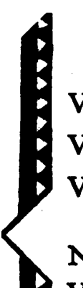

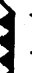

Vitamin A - -280 i.u. Manganese - $-4.0 \mathrm{mg}$. Vitamin $B_{1} 250$ i.u. (0.75mg.) Iron - - $2.7 \mathrm{mg}$. Vitamin $B_{2}$ (Riboflavin) Copper - $-0.45 \mathrm{mg}$. $0.3 \mathrm{mg}$. Protein - $\quad 30 \%$ Nicotinic Acid - $1.7 \mathrm{mg}$. Available Carbohydrate $39 \%$

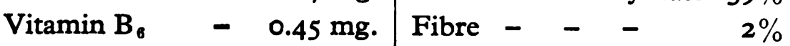
Vitamin E - $\quad 8.0 \mathrm{mg}$. Calorific Value - 104 